\title{
Tuber Yield and Starch Content as Influenced by Different Grades of Micronutrient Mixture at Different Levels in Cassava under Irrigated Condition
}

\author{
S. Suganya ${ }^{1 *}$, D. Jegadeeswari ${ }^{2}$ and T. Chitdeshwari ${ }^{2}$ \\ ${ }^{1}$ TNAU-Information and Training Centre, Chennai, India \\ ${ }^{2}$ Department of SS\&AC, TNAU, Coimbatore, India \\ *Corresponding author
}

\begin{abstract}
A B S T R A C T
Cassava (Manihot esculenta Crantz) is a perennial shrub and a tuberous root crop well adapted to poor soils and is relatively tolerant to drought, the crop is usually grown under marginal soil and climatic conditions and often with very limited inputs of fertilizers and pesticides. In India, cassava is cultivated in varied agro climatic and pedogenic environments. In Tamil Nadu, it is cultivated mainly for industrial uses, cassava is grown in black soils (Vertisols) and red soils (Alfisols). Cassava nutrient management by blanket fertilizer recommendations over wide areas and soil types over the past 40 years or so in India have resulted in significant yield increase. But when we extrapolate the results from experimental stations to farmers' fields, the yield cannot be increased beyond a certain level due to the high temporal and spatial variability of soil and plant nutrients. Alleviation of micronutrient deficiencies to improve crop yields is difficult to large temporal and spatial variation in phyto availability of soil micronutrients. The easiest and most straight forward practice to correct micronutrient deficiency is to apply micronutrient fertilizers. Soil application of fertilizer is economically more affordable. Four field experiments were conducted to evaluate three different grades of micronutrient mixtures at graded doses for increasing the productivity and starch content in cassava under irrigated condition. The experiment was conducted in Factorial RBD replicated thrice with Main factor as micronutrient mixture grades (Grade I, Grade 2 and Grade 3) and sub factor as dose of micronutrient mixture $\left(0,10,15,20\right.$ and $\left.30 \mathrm{~kg} \mathrm{ha}^{-1}\right)$ in two different soils with calcareous and non-calcareous soil in Pethanaickanpalayam block of Salem district during Jan-Feb 2018. Observations on tuber yield and starch content were recorded in all the four experiments. Among the treatments, application of grade 2 micronutrient mixture at $30 \mathrm{~kg} \mathrm{ha}^{-1}$ application recorded significantly higher tuber yield (36.8, 35.2, 30.4 and $\left.32.1 \mathrm{t} \mathrm{ha}^{-1}\right)$ and starch content $(25.2,32.0,24.2$ and $24.1 \%)$ respectively in YTP 1, MVD 1, Kungumarose and YTP 1 varieties at red non calcareous, red calcareous, black non calcareous and black calcareous soil respectively which was on par with the application of grade 2 at $20 \mathrm{~kg} \mathrm{ha}^{-1}$ application. Hence, application of grade 2 micronutrient mixture at $20 \mathrm{~kg} \mathrm{ha}^{-1}$ application can be recommended for getting higher tuber yield and starch content besides alleviating micronutrient deficiency and maintaining fertility of cassava growing soils in Tamil Nadu.
\end{abstract}

\section{Introduction}

Cassava (Manihot esculenta Crantz) is a perennial shrub and a tuberous root crop and is a native of Tropical America and was introduced from Brazil into India by the
Portuguese in the $17^{\text {th }}$ century. The importance of cassava as a food and industrial crop relies on its roots since they accumulate starch (approximately 30-60\% dry matter) and so, it is considered the second source of starch globally, after maize (FAO, 2013). 
Cassava is well adapted to poor soils and is relatively tolerant to drought, the crop is usually grown under marginal soil and climatic conditions and often with very limited inputs of fertilizers and pesticides. In India, cassava is cultivated in varied agro climatic and pedogenic environments.In India, it is cultivated in 2.07 lakh ha with the production of 72.37 lakh MT. The leading cassava producing states are Tamil Nadu $(62.50 \%)$ followed by Kerala (33.97\%). In Tamil Nadu, it is cultivated mainly in Salem, Namakkal, Dharmapuri, Villupuram and Erode districts for industrial uses and grown in black soils (Vertisols) and red soils (Alfisols). Cassava is extensively cultivated as an annual crop in tropical and subtropical regions for its edible starchy tuberous root and as a major source of carbohydrates (Kenneth, 2011). Most of the cultivated areas have started showing signs of stress with production fatigue and deterioration of soil health. In these areas, yields have started declining because of deterioration in total factor productivity, decline in soil organic matter content and emergence of multinutrient deficiencies. Growing of cassava under calcareous soils can reduce yields by causing more severe deficiencies of micronutrients. In calcareous soil the crop may suffer from zinc and or iron deficiency which leads to lesser tuber yield as well as starch content. Cassava is highly responsive to manures and fertilizers including secondary and micronutrients (Susan John et al., 2011). Micronutrients such as zinc, manganese, iron, copper and boron are generally deficient in most cassava growing soils as these elements are decreased rapidly by precipitation or by soil adsorption, especially in high $\mathrm{pH}$ (Howeler et al., 1982; Howeler, 2002; Lee and Saunders, 2003). In calcareous soils, copper, iron, manganese and zinc are rendered less available as these elements precipitate in soils to form carbonates or bicarbonates and the elements are also less available in high organic matter soils. Cassava can also encounter zinc and iron deficiency and severe copper deficiency resulting in $30 \%$ yield reductions. During the growing season, plants require a balanced and sufficient supply of all the nutrients for maximum growth and yield. In this context, it is hypothesized that evaluation of micronutrient mixture ensures alleviating micronutrient deficiencies and provides balanced nutrition to crops thereby increasing the productivity and starch content in cassava.

\section{Materials and Methods}

The field experiment was conducted in Factorial Randomized Block Design (FRBD) replicated thrice with the following technical programme in two different soils with calcareous and non-calcareous soil viz., Red non-calcareous at TCRS farm, Red calcareous at Thalavaipatty village, Black non calcareous soil at Umayalpuram village and Black calcareous at Ramanaickanpalayam village of Pethanaickanpalayam block of Salem district during Jan-Feb 2018.

\section{Treatment details}

Main factor: Micronutrient mixture grades

$\mathrm{M}_{1}$ - Grade I

$\mathrm{M}_{2}$ - Grade II

$\mathrm{M}_{3}$ - Grade III

Sub factor: Dose of Micronutrient mixture

$\mathrm{S}_{1}-0 \mathrm{~kg} \mathrm{ha}^{-1}$

$\mathrm{S}_{2}-10 \mathrm{~kg} \mathrm{ha}^{-1}$

$\mathrm{S}_{3}-15 \mathrm{~kg} \mathrm{ha}^{-1}$

$\mathrm{S}_{4}-20 \mathrm{~kg} \mathrm{ha}^{-1}$

$\mathrm{S}_{5}-30 \mathrm{~kg} \mathrm{ha}^{-1}$

Note: All grades of micronutrient mixture Method of application - Soil (Basal)

The initial soil of all the four field experiment was collected, analysed for their physico- 
chemical characteristics and results are given in the table 1. Observations on tuber yield and starch content were recorded in all the four experiments.

\section{Results and Discussion}

Influence of micronutrient mixture on tuber yield and starch content of cassava in red and black calcareous and non-calcareous soils are presented in the following tables (Table 2 to $5)$.

Significant influence of different treatment combinations on tuber yield was observed. among the different grades, significantly the maximum tuber yield $\left(32.2 \mathrm{t} \mathrm{ha}^{-1}\right)$ was recorded by the application of grade 2 micronutrient mixture (M2) followed by grade 1 which was on par with grade 3 .

With respect to dose of micronutrient mixture, application at $30 \mathrm{~kg} \mathrm{ha}^{-1}$ (S5) significantly recorded the maximum tuber yield $(35.5 \mathrm{t}$ ha ${ }^{1}$ ) which was on par with application at $20 \mathrm{~kg}$ $\mathrm{ha}^{-1}$ (S4) and significantly minimum tuber yield (26.1 $\mathrm{t} \mathrm{ha}^{-1}$ ) was recorded by the application at $0 \mathrm{~kg} \mathrm{ha}^{-1}$ (S1). Among the interaction effect application of M2 micronutrient mixture grade at $30 \mathrm{~kg} \mathrm{ha}^{-1}$ (M2S5) recorded the maximum tuber yield (36.8 $\mathrm{t} \mathrm{ha}^{-1}$ ) in red non calcareous soil at TCRS farm with cassvaa YTP 1 variety.

In red calcareous soil at Thalavaipatty field the tuber yield (31.7 $\mathrm{t} \mathrm{ha}^{-1}$ ) was significantly higher by the application of grade 2 micronutrient mixture (M2) followed by M1 which was on par with M3.

With regard to dose of application, the tuber yield $\left(34.5 \mathrm{t} \mathrm{ha}^{-1}\right)$ was significantly higher at $30 \mathrm{~kg} \mathrm{ha}^{-1}$ (S5) application which was on par with S4 and application of micronutrient mixture at $0 \mathrm{~kg} \mathrm{ha}^{-1}$ recorded significantly lesser tuber yield of $26.5 \mathrm{~kg} \mathrm{ha}^{-1}$.
Among the interaction effect application of M2S5 treatment recorded significantly higher tuber yield (35.2 $\mathrm{t} \mathrm{ha}^{-1}$ ) of MVD 1 variety. A similar trend was followed in black non calcareous and calcareous soil at Umayalpuram and Ramanaickanpalayam village.

Significantly the maximum starch content (23.6\%) was recorded by the application of M2 grade 2 micronutrient mixture followed by grade 1 (M1) which was on par with grade 3 (M3). Among the different doses, application at $30 \mathrm{~kg} \mathrm{ha}^{-1}$ (S5) significantly recorded maximum starch content $(24.0 \%)$ which was on par with $20 \mathrm{~kg} \mathrm{ha}^{-1}$ application dose (S4) and application at $0 \mathrm{~kg} \mathrm{ha}^{-1}$ (S1) recorded significantly the minimum starch content of $21.4 \%$. With regard to interaction effect, application of M2S5 recorded significantly the maximum starch content of cassava YTP 1 in red non calcareous soil at TCRS farm.

Similarly application of grade 2 micronutrient mixture (M2) recorded significantly more starch content $(29.1 \%)$ in cassava MVD 1 variety followed by M1 and M3 (28.2 and $28.3 \%$ respectively).

Among the doses, application at $30 \mathrm{~kg} \mathrm{ha}^{-1}$ (S5) recorded significantly more starch content $(30.9 \%)$ which was on par with the application at $20 \mathrm{~kg} \mathrm{ha}^{-1}$ (S4) and lesser starch content $(26.4 \%)$ was recorded at $0 \mathrm{~kg} \mathrm{ha}^{-1}$ application. With respect to interaction effect application of grade 2 (M2) at $30 \mathrm{~kg} \mathrm{ha}^{-1}$ application recorded significantly maximum starch content $(32.0 \%)$ in cassava MVD 1 variety in red calcareous soil at Thalavaipatty village.

A similar trend was followed in black non calcareous and calcareous soil at Umayalpuram and Ramanaickanpalayam village with Kungumarose and TTP 1 cassava 
variety. Combination of foliar application of $\mathrm{Zn}, \mathrm{K}$ and $\mathrm{Mg}$ had a positive effect on yield and yield attributes The increased tuber yield was also associated with the corresponding significant increase in number of tubers per plant, tuber length and tuber girth. The application of zinc is necessary for obtaining good yield.

The increase in the rate of photosynthesis and activity of carbonic anhydrase with combination of $\mathrm{Fe}$ and $\mathrm{Zn}$ application is the main reason for improving yield. This might be due to carbonic anhydrase and auxin production by $\mathrm{Zn}$ and $\mathrm{Fe}$ is necessary for the biosynthesis of chlorophyll.

Uthaiwan Kanto et al., (2011) in their study reported that combination of organics like swine manure, cow dung and inorganic micronutrients has increased tuber yield and starch content in cassava. This combination of nutrients may contain plant growth regulators, macronutrients and micronutrients which might have a role in enhancing starch content.

Oyetunji et al., (2003) revealed that the introduced AM fungi were able to enhance $\mathrm{Fe}, \mathrm{Zn}$ and $\mathrm{Cu}$ uptakes in field condition. $\mathrm{Fe}$ and $\mathrm{Cu}$ were significantly partitioned to roots while the tissue concentration of $\mathrm{Zn}$ was higher in shoots than in roots. Introduction of exotic AM fungi can improve cassava micronutrient uptake under alley cropping where competition for nutrient uptake is strong.

Susan John et al., (2011) also recommended that soil test based $\mathrm{Zn}$ recommendation resulted in a significantly higher tuber yield of $42.19 \mathrm{t} \mathrm{ha}^{-1}$ where the soil $\mathrm{Zn}$ status was between $0.19-0.85 \mathrm{mg} \mathrm{kg}^{-1}$. Foliar fertilizer treatment with zinc, magnesium and sulfur had greater effects on yield and quality of cassava root (Panitnok et al., 2013). Micronutrients viz., manganese, zinc and iron are essential for cassava growth, tuber yield and its quality; they play an important role in balance crop nutrition (Mousavi et al., 2011). Application of zinc stimulated the vegetative growth characters, improved tuber yield and quality. Moreover, $\mathrm{Zn}$ and $\mathrm{Mn}$ application increased the tuber yield and its quality of cassava. These findings are in line with the Mousavi et al., (2007).

Ali and Abd-Elkader (2014) also revealed that application systems of Potassium sulphate up to five equal doses and foliar application of micronutrient mixtures levels up to $30 \%$ is the most efficient combination treatment, which gave the best results for tuberous roots yield of cassava plants grown in sandy soil.

The stimulating effects of the micronutrients mixtures on cassava plants can be attributed based on the micronutrients viz., $\mathrm{Zn}, \mathrm{Fe}$ and $\mathrm{Mn}$ are essential for plant growth, crop yield and its quality, they play an important role in balance crop nutrition . Moreover micronutrients had role in increasing photosynthesis efficiency and synthesis of carbohydrates such as starch (Mousavi et al., 2012).

Micronutrients play a critical role for growth and yield of cassava, which is widely grown under poor soil fertility and micronutrient deficiency conditions. Zinc is an essential element needed in many enzymatic reactions, including dehydrogenases, proteinases, and peptidases to aid molecular configurations between an enzyme and a substrate (Fergeria et al., 2010).

Foliar spray of $2 \% \mathrm{ZnSO}_{4}$ increased biomass yield in all cassava genotypes by $30.6 \%$ to 75.7\% (Anon Janket et al., 2018). Parkes et al., (2012) reported that the higher percent starch content in cassava tuberous root of F2 genotype was achieved with fertilizers rate along with micronutrient mixture. 
Table.1 Initial soil characteristics of the field experiment

\begin{tabular}{|c|c|c|c|c|c|}
\hline \multirow[t]{3}{*}{ S.No. } & Soil characteristics & $\begin{array}{l}\text { Red non } \\
\text { calcareous }\end{array}$ & $\begin{array}{c}\text { Red } \\
\text { calcareous }\end{array}$ & $\begin{array}{l}\text { Black non } \\
\text { calcareous }\end{array}$ & $\begin{array}{c}\text { Black } \\
\text { calcareous }\end{array}$ \\
\hline & Location & $\begin{array}{l}\text { TCRS farm, } \\
\text { P.G.Palayam, } \\
\text { Yethapur }\end{array}$ & $\begin{array}{c}\text { Thalavaipatty } \\
\text { village }\end{array}$ & $\begin{array}{l}\text { Umayalpuram } \\
\text { village }\end{array}$ & $\begin{array}{c}\text { R.N. Palayam } \\
\text { village }\end{array}$ \\
\hline & Name of the Farmer & TCRS farm & Th.Murugesan & Th.Pachamuthu & Th. Ganesan \\
\hline 1. & $\mathrm{pH}$ & 7.60 & 7.54 & 7.58 & 7.62 \\
\hline 2. & $\mathrm{EC}\left(\mathrm{d} \mathrm{Sm}^{-1}\right)$ & 0.40 & 0.34 & 0.30 & 0.43 \\
\hline 3. & Organic carbon $(\%)$ & 0.40 & 0.43 & 0.41 & 0.45 \\
\hline 4. & Available $\mathrm{N}\left(\mathrm{kg} \mathrm{ha}^{-1}\right)$ & 225 & 245 & 231 & 258 \\
\hline 5. & Available P $\left(\mathrm{kg} \mathrm{ha}^{-1}\right)$ & 4.25 & 6.82 & 13.57 & 16.48 \\
\hline 6. & Available $\mathrm{K}\left(\mathrm{kg} \mathrm{ha}^{-1}\right)$ & 332 & 324 & 375 & 389 \\
\hline 7. & $\begin{array}{l}\text { Available } \mathrm{Zn} \\
\left(\mathrm{mg} \mathrm{kg}^{-1}\right)\end{array}$ & 0.50 & 0.68 & 0.88 & 0.61 \\
\hline 8. & $\begin{array}{l}\text { Available Fe } \\
\left(\mathrm{mg} \mathrm{kg}^{-1}\right)\end{array}$ & 3.21 & 6.48 & 3.13 & 7.98 \\
\hline 9. & $\begin{array}{l}\text { Available Mn } \\
\left(\mathrm{mg} \mathrm{kg}^{-1}\right)\end{array}$ & 1.42 & 3.78 & 1.64 & 4.25 \\
\hline 10. & $\begin{array}{l}\text { Available } \mathrm{Cu} \\
\left(\mathrm{mg} \mathrm{kg}^{-1}\right)\end{array}$ & 0.94 & 2.18 & 0.88 & 3.10 \\
\hline 11. & $\begin{array}{l}\text { Available B } \\
\left(\mathrm{mg} \mathrm{kg}^{-1}\right)\end{array}$ & 0.36 & 0.33 & 0.46 & 0.66 \\
\hline
\end{tabular}

Table. 2 Influence of micronutrient mixture on the tuber yield $\left(\mathrm{t} \mathrm{ha}^{-1}\right)$ of cassava in red non calcareous and red calcareous soil

\begin{tabular}{|c|c|c|c|c|c|c|c|c|}
\hline \multirow[t]{2}{*}{ Trt } & \multicolumn{4}{|c|}{$\begin{array}{l}\text { Tuber yield of cassava in } \\
\text { Red Non calcareous soil } \\
\text { at TCRS farm }\end{array}$} & \multicolumn{4}{|c|}{$\begin{array}{c}\text { Tuber yield of cassava in } \\
\text { Red Calcareous soil } \\
\text { at Thalavaipatty village }\end{array}$} \\
\hline & M1 & M2 & M3 & Mean & M1 & M2 & M3 & Mean \\
\hline S1 & 26.1 & 26.3 & 25.9 & 26.1 & 26.4 & 27.1 & 25.9 & 26.5 \\
\hline $\mathbf{S 2}$ & 28.2 & 30.5 & 28.5 & 29.1 & 27.8 & 30.2 & 28.1 & 28.7 \\
\hline S3 & 31.6 & 32.2 & 31.4 & 31.7 & 30.9 & 31.9 & 30.4 & 31.1 \\
\hline S4 & 33.8 & 35.1 & 33.8 & 34.2 & 32.8 & 34.1 & 33.2 & 33.4 \\
\hline S5 & 35.5 & 36.8 & 34.1 & 35.5 & 34.1 & 35.2 & 34.3 & 34.5 \\
\hline \multirow[t]{2}{*}{ Mean } & 31.0 & 32.2 & 30.7 & & 30.4 & 31.7 & 30.4 & \\
\hline & $\mathbf{M}$ & $\mathbf{S}$ & MxS & & & $\mathbf{M}$ & $\mathbf{S}$ & MxS \\
\hline SEd & 0.58 & 1.46 & 1.37 & & SEd & 0.65 & 1.57 & 1.67 \\
\hline $\mathrm{CD}(\mathrm{P}=\mathbf{0 . 0 5})$ & 1.15 & 2.94 & 2.89 & & $\begin{array}{c}\text { CD } \\
(\mathbf{P}=\mathbf{0 . 0 5})\end{array}$ & 1.29 & 3.15 & 3.37 \\
\hline
\end{tabular}


Table.3 Influence of micronutrient mixture on the tuber yield $\left(\mathrm{t} \mathrm{ha}^{-1}\right)$ of cassava in black calcareous and black non calcareous soil

\begin{tabular}{|c|c|c|c|c|c|c|c|c|}
\hline \multirow[t]{2}{*}{ Trt } & \multicolumn{4}{|c|}{$\begin{array}{l}\text { Tuber yield of cassava in } \\
\text { Black Non calcareous soil } \\
\text { at Umayalpuram village }\end{array}$} & \multicolumn{4}{|c|}{$\begin{array}{l}\text { Tuber yield of cassava in } \\
\text { Black Calcareous soil at } \\
\text { Ramanaickanpalayam village }\end{array}$} \\
\hline & M1 & M2 & M3 & Mean & M1 & M2 & M3 & Mean \\
\hline S1 & 22.6 & 22.9 & 22.1 & 22.5 & 22.1 & 22.3 & 21.9 & 22.1 \\
\hline S2 & 24.3 & 25.6 & 24.0 & 24.6 & 24.5 & 28.5 & 24.7 & 25.9 \\
\hline S3 & 25.7 & 27.1 & 25.9 & 26.2 & 28.2 & 29.2 & 27.5 & 28.3 \\
\hline S4 & 26.8 & 28.3 & 27.2 & 27.4 & 30.2 & 30.1 & 30.2 & 30.2 \\
\hline S5 & 28.4 & 30.4 & 29.3 & 29.4 & 32.4 & 32.1 & 30.0 & 31.5 \\
\hline \multirow[t]{2}{*}{ Mean } & 25.6 & 26.9 & 25.7 & & 27.5 & 28.4 & 26.9 & \\
\hline & M & $\mathbf{S}$ & MxS & & & M & $\mathbf{S}$ & MxS \\
\hline SEd & 0.58 & 1.56 & 1.68 & & SEd & 0.48 & 1.34 & 1.37 \\
\hline $\mathrm{CD}(\mathrm{P}=0.05)$ & 1.18 & 3.10 & 3.42 & & $\begin{array}{c}\text { CD } \\
(P=0.05)\end{array}$ & 1.02 & 2.68 & 2.89 \\
\hline
\end{tabular}

Table.4 Influence of micronutrient mixture on the starch content $(\%)$ of cassava in red calcareous and red non calcareous soil

\begin{tabular}{|c|c|c|c|c|c|c|c|c|}
\hline \multirow{2}{*}{ Trt } & \multicolumn{3}{|c|}{$\begin{array}{c}\text { Red Non calcareous soil } \\
\text { at TCRS farm }\end{array}$} & \multicolumn{3}{c|}{ Red Calcareous soil at Thalavaipatty } \\
& \multicolumn{3}{|c|}{ village } \\
\cline { 2 - 9 } & M1 & M2 & M3 & Mean & M1 & M2 & M3 & Mean \\
\hline S1 & 21.3 & 21.7 & 21.1 & 21.4 & 26.1 & 26.7 & 26.4 & 26.4 \\
\hline S2 & 21.5 & 22.4 & 22.0 & 22.0 & 27.2 & 27.5 & 27.0 & 27.2 \\
\hline S3 & 22.5 & 23.5 & 22.5 & 22.8 & 28.0 & 28.7 & $28 . .4$ & 28.4 \\
\hline S4 & 23.2 & 25.1 & 23.3 & 23.5 & 29.2 & 30.5 & 29.7 & 29.8 \\
\hline S5 & 24.0 & 25.2 & 23.7 & 24.0 & 30.5 & 32.0 & 30.1 & 30.9 \\
\hline Mean & 22.5 & 23.6 & 22.5 & & 28.2 & 29.1 & 28.3 & \\
\hline & $\mathbf{M}$ & $\mathbf{S}$ & $\mathbf{M x S}$ & & $\mathbf{M}$ & $\mathbf{S}$ & $\mathbf{M x S}$ & \\
\hline SEd & 0.28 & 0.32 & 0.41 & & $\mathbf{S E d}$ & 0.37 & 0.49 & 0.62 \\
\hline $\mathbf{C D}(\mathbf{P = 0 . 0 5 )}$ & 0.50 & 0.68 & 1.10 & & $\mathbf{C D}$ & 0.81 & 1.13 & 1.32 \\
\hline
\end{tabular}

Table.5 Influence of micronutrient mixture on the starch content (\%) of cassava in black calcareous and black non calcareous soil

\begin{tabular}{|c|c|c|c|c|c|c|c|c|}
\hline \multirow{2}{*}{ Trt } & \multicolumn{3}{|c|}{$\begin{array}{c}\text { Black Non calcareous } \\
\text { at Umayalpuram village }\end{array}$} & \multicolumn{4}{c|}{$\begin{array}{c}\text { Black Calcareous soil at } \\
\text { Ramanaickanpalayam village }\end{array}$} \\
\cline { 2 - 10 } & M1 & M2 & M3 & Mean & M1 & M2 & M3 & Mean \\
\hline S1 & 21.3 & 21.7 & 21.1 & 21.4 & 20.5 & 21.2 & 20.4 & 20.7 \\
\hline S2 & 21.5 & 22.4 & 22.0 & 22.0 & 21.6 & 21.8 & 20.7 & 21.4 \\
\hline S3 & 22.5 & 23.5 & 22.5 & 22.8 & 22.1 & 22.9 & 22.0 & 22.3 \\
\hline S4 & 23.2 & 24.1 & 23.3 & 23.5 & 23.1 & 23.6 & 22.9 & 23.2 \\
\hline S5 & 24.0 & 24.2 & 23.7 & 24.0 & 23.8 & 24.1 & 23.6 & 23.8 \\
\hline Mean & 22.5 & 23.2 & 22.5 & & 22.2 & 22.7 & 21.9 & . \\
\hline & M & S & MxS & & & M & S & MxS \\
\hline SEd & 0.34 & 0.59 & 0.59 & & SEd & 0.25 & 0.38 & 0.42 \\
\hline CD (P=0.05) & 0.68 & 1.19 & 1.28 & & CD & 0.48 & 0.75 & 0.86 \\
\hline
\end{tabular}


Among the treatments, application of grade 2 (M2) micronutrient mixture dose at $30 \mathrm{~kg} \mathrm{ha}^{-1}$ application (S5) recorded significantly higher tuber yield (36.8, 35.2, 30.4 and $32.1 \mathrm{t} \mathrm{ha}^{-1}$ ) and starch content $(25.2,32.0,24.2$ and $24.1 \%$ ) respectively in YTP 1, MVD 1, Kungumarose and YTP 1 varieties at red non calcareous, red calcareous, black non calcareous and black calcareous soil respectively which was on par with the application of grade 2 at $20 \mathrm{~kg} \mathrm{ha}^{-1}$ application (S4).

Hence, application ofgrade 2 micronutrient mixture at $20 \mathrm{~kg} \mathrm{ha}^{-1}$ application under irrigated condition can be recommended for getting higher tuber yield and starch content besides alleviating micronutrient deficiency and maintaining fertility of cassava growing soils in Tamil Nadu.

\section{References}

Ali, R. A. M. and D. Y. Abd-Elkader. 2014. Influence of application systems of $\mathrm{K}_{2} \mathrm{SO}_{4}$ and foliar application of Micronutrient mixtures on cassava grown in sandy soil. Alexandria Science Exchange Journal. Vol. 35.(4).314-324.

Anon Janket, NimitrVorasoot, ThawanKesmala and SanunJogloy. 2018. Influence of zinc, copper and manganese on dry matter yield and physiological traits of three cassava genotypes grown on soil micronutrient deficiencies. Pak. J. Bot.50 (5): 17191725 .

FAO. 2013. Save and grow cassava: a guide to sustainable production and identification. E-ISBN: 978-92-5-107642-2.

Fergeria, N. K., V. C. Baliger and C. A. Jones. 2010. Growth and mineral nutrition of field crops. CRC Press, Florida.

Howeler, R. H. 2002. Cassava mineral nutrition and fertilization. In: Hillocks R.J., M. J. Thresh, and A. C. Belloti (Eds.) Cassava: Biology, Production and Utilization. $C A B$ International, Wallingford, pp. 115-147.

Howeler, R., D. G. Edvards. And C. J. Asher. 1982. Micronutrient deficiencies and toxicities of cassava plants grown in nutrient solutions. I. Critical tissue concentrations. J. Plant Nut., 5(8): 10591076.

Kenneth, V. R. 2011. Evaluation of three cassava varieties for tuber quality and yield. Gladstone Road Agri. Cent. Cro. Res. Rep. No. 4.

Lee, M. K. and J. A. Saunders. 2003. Effects of $\mathrm{pH}$ on metals precipitation and sorption: Field bioremediation and geochemical modeling approaches. Vadose Zone J., 2: 177-185.

Mousavi, S. R., M. G mnalavi and G. Ahmadvan. 2007. Effect of zinc and manganese foliar application on yield, quality and enrichment on potato (Solanum tuberosum L). Asi. J. Pla. Sci.6(8): 1256-1260.

Mousavi, S. R., M. Galavi. and M. Rezaei. 2012. The interaction of zinc with other elements in plants: a review. Intl J Agr. Cro. Sci. 4(24): 1881-1884.

Mousavi, S. R., M. Shanhsavari and M. Rezaei. 2011. A General overview on manganese $(\mathrm{Mn})$ importance for crops production. Aust. J. Basic \& Appl. Sci., 5(9): 1799-1803.

Oyetunji, O.J., I. J. Ekanayake., O. Osonubi. andO. Lyasse. 2003. Cassava macro and micronutrient uptake and partitioning in alley cropping system as influence by Glomus spp. in sub-humid tropics and its impact on productivity.url: http://www.ciat.cgiar.org/biotechnology /cbn/sixth international meeting/poster.

Panitnok, K., S. Chaisri., E.D. Sarobol., S. Ngamprasithi and P. Chaisir. 2013. The combination effects of zinc, 
magnesium, sulphur foliar fertilizer management on cassava growth and yield and yield grown on map bon, coarse-loamy variant soil. Proc. Soc.\&Beh. Sci. 91(2): 288-293.

Parkes, E. Y., D.F.K. Allotey, E. Lotsu and E. A. Akuffo. 2012. Yield performance of five cassava genotypes under different fertilizer rates. Inte. J. Agric. Sci. 2(5): 173-177.

Susan John, K., Ravindran, C.S., Suja, G., Prathapan, K., Naskar, S. K. and James George. 2011. Response of cassava to zinc: Two decades experience in an Ultisol of Kerala, India. In: Extended Abstracts, $\quad 3^{\text {rd }}$ International $\quad \mathrm{Zn}$ Symposium, Hyderabad, India, 10-14 October, 2011, pp. 27-28.

Uthaiwan Kanto, KanapolJutamanee, Yongyuth Osotsapar, Sukanya Jattupurnpong and Chongrak Kaewprasit. 2011. Effect of Swine Manure Extract by Foliar application and Soil drenching on Dry matter and Nutrient uptake of Cassava. Kasetsart J. (Nat. Sci.) 45: 995-1005.

\section{How to cite this article:}

Suganya, S., D. Jegadeeswari and Chitdeshwari, T. 2020. Tuber Yield and Starch Content as Influenced by Different Grades of Micronutrient Mixture at Different Levels in Cassava under Irrigated Condition. Int.J.Curr.Microbiol.App.Sci. 9(05): 3140-3147. doi: https://doi.org/10.20546/ijcmas.2020.905.372 